\title{
Peran Tokoh Agama dalam Pembinaan Harmonisasi Kehidupan dan Akhlak Masyarakat di Kota Metro Lampung
}

\author{
Ida Umami \\ Institut Agama Islam Negeri (IAIN) Metro \\ E-mail: alidaumami@yahoo.com
}

\begin{abstract}
Religious figures basically have a very important and strategic position and role, mainly as a spiritual, moral and ethical foundation in the life and life of mankind. a religious figure is a figure or role model in society. Has a position and great influence in the midst of society, because it has advantages, both in science, integrity, and so forth. Religious figures also serve as community leaders, as priests in religious matters and community issues and state affairs in order to succeed government programs and foster community life harmonization. Religion as a value system must be understood, lived and practiced by all adherents in the life order of every individual, family and society and animates the life of the nation and the state. The current situation of harmonization and community behavior requires the role of religious leaders to be significantly expected to take the initiative in the development and development of morality. This means that every development effort must always be directed to have a positive impact on character development.
\end{abstract}

Key Word: Religious Figures and Character Development

\begin{abstract}
Abstrak
Tokoh agama pada dasarnya memiliki posisi yang sangat penting dan strategis dan peran, terutama sebagai landasan spiritual, moral dan etika dalam hidup dan kehidupan umat manusia. tokoh agama adalah sosok atau panutan dalam masyarakat. Memiliki posisi dan pengaruh yang besar di tengah-tengah masyarakat, karena memiliki kelebihan, baik
\end{abstract}


dalam ilmu, integritas, dan lain sebagainya. tokoh agama juga berfungsi sebagai tokoh masyarakat, sebagai imam dalam urusan agama dan isu-isu masyarakat dan urusan negara dalam rangka untuk berhasil program pemerintah dan asuh harmonisasi kehidupan masyarakat. Agama sebagai sistem nilai harus dipahami, berumur dan dipraktekkan oleh semua penganut dalam urutan kehidupan setiap individu, keluarga dan masyarakat dan menjiwai kehidupan bangsa dan negara. Situasi saat ini harmonisasi dan perilaku masyarakat membutuhkan peran pemimpin agama secara signifikan diharapkan untuk mengambil inisiatif dalam pengembangan dan pembangunan moralitas. Ini berarti bahwa setiap upaya pembangunan harus selalu diarahkan untuk memiliki dampak positif pada pengembangan karakter.

Kata Kunci: Tokoh Agama dan Pengembangan Karakter

\section{A. Pendahuluan}

\section{Latar Belakang}

Di era globalisasi atau modern saat ini, persoalan bangsa ternyata semakin menjadi-jadi, hal ini karena bangsa ini mengalami persoalan krisis akidah dan syari'ah. pendangkalan pemahaman agama menjadi suatu trand dalam masyarakat, diikuti oleh masyarakat awam sampai kaum terpelajar, dogma agama yang ditafsirkan sekendak hati/ sesuai dengan keinginan seseorang atau oleh kelompok tertentu (radikalisme). Al-Qur'an dan hadits Rasulullah SAW semakin dijauhkan. Oleh karena itu, menurut $M$. Dawam Raharjo, institusi atau lembaga penangkal seperti keberadaan pondok pesantren menjadi sangat penting. Hal itu menjadi identitas lingkungan masyarakat pada awal pertumbuhannya, yaitu sebagai pusat penyebaran agama Islam, di samping sebagai sebuah lembaga pendidikan ${ }^{1}$.

${ }^{1}$ M.Dawam Raharjo, "Perkembangan Masyarakat dalam Perspektif Lingkungan masyarakat”, (Jakarta : P3M, 1985), h. vii. 
Tokoh agama pada dasarnya mempunyai kedudukan dan peranan yang sangat penting dan strategis, utamanya sebagai landasan spiritual, moral dan etika dalam hidup dan kehidupan umat manusia. Agama sebagai sistem nilai harus dipahami, dihayati dan diamalkan oleh seluruh pemeluknya dalam tatanan kehidupan setiap individu, keluarga dan masyarakat serta menjiwai kehidupan berbangsa dan bernegara.

Selain itu pula, tokoh agama adalah seorang figur atau panutan dalam masyarakat yang mempunyai kedudukan dan pengaruh besar di tengah-tengah masyarakatnya, karena memiliki keunggulan, baik dalam ilmu pengetahuan, integritas, dan lain sebagainya. Tokoh Agama pun berperan sebagai pemimpin masyarakat, sebagai imam dalam masalah agama dan masalah kemasyarakatan serta masalah kenegaraan dalam rangka mensukseskan program pemerintah dan pembinaan harmonisasi kehidupan masyarakat.

Namun pada kenyataanya di masyarakat, seringkali peran para tokoh agama kurang optimal dalam pembinaan harmonisasi dan akhlak masyarakat. Akibatnya internalisasi nilai-nilai moral, iman dan taqwa (Imtaq), yang sesungguhnya perlu ditanamkan pada masyarakat sangat kurang. Sehingg perilaku masyarakat cenderung pada manusia yang mempunyai intelektualitas tinggi, tetapi tidak diikuti oleh kematangan pribadi dan kematangan emosional yang seimbang, sehingga efek emosinya tidak mampu mengimbangi konsep intelektualitasnya yang hanya berdasarkan pada perhitungan rasional dan menguntungkan diri sendiri. Kondisi demikian tentu saja akan menjadi kendala dalam pencapaian harmonisasi kehidupan dalam masyarakat.

Situasi harmonisasi dan perilaku masyarakat saat ini membutuhkan peran dari para tokoh agama secara signifikan 
seta diharapkan mampu mengambil inisiatif dalam pembinan dan pengembangan akhlak msyarakat. Hal iniberarti bahwa settiap upaya pembangunan harus selalu diarahkan untuk memberi dampak positif terhadap pengembangan karakter. ${ }^{2}$

Kenyataan yang berkembang di masyarakat pada saat ini sangat menghkawatirkan dan mengancam kebinekaan. Ujaran kebencian serta saling menghujat baik secara terus terang maaupun dalam media social menjadi hal yang lumrah dilakukan. Gerakan radikalisme yang mengancam aqidah juga semakin masif dilaakukan. Oleh karena itu, peran para ulama dan tokoh agama terhadap harmonisasi kehidupan masyarakat sangatlah diperlukan. Hal ini dikuatkan dengan hasil penelitian Laurentius Yananto Andi Prasetyo yang dilaksanakan pada tahun 2013 tentang peran tokoh lintas agama dalam menangkal gerakan radikalisme agama dan implikasinya terhadap ketahanan wilayah (Studi Pada Komunitas Tokoh Lintas Agama di Kota Surakarta, Jawa Tengah) yang dipublikasikan dalam Jurnal Ketahanan Nasional.

Berdasarkan beberapa permasalahan tersebut di atas, maka penelitian terhadap peran tokoh agama dalam pembinan harmonisasi dan akhlak di lingkungan masyarakat Kota Metro mendesak untuk dilakukan guna memperoleh solusi dan menjawab berbagi permasalahan dalam upaya mewujudkan pembinaan harmonisasi kehidupan dan akhlak masyark secaralebih optimal.

\section{Rumusan Masalah}

Permasalahan dalam penelitian ini dapat dirumuskan sbagai berikut 1) Bagaimana peran tokoh agama dalam pembinan harmonisasi dan akhlak di lingkungan masyarakat,

2 Zubaedi, Desain Pendidikan Karakter: Konsepsi dan Aplikasinya dalam Lembaga Pendidikan, (Jakarta: Kencana,2011), h.7 
2) kekuatan apa saja yag menjadi factor pendukung dalam pelaksanaan peran tokoh agama dalam pembinan harmonisasi dan akhlak di lingkungan masyarakat, 3) Kelemahan apa saja yag menjadi factor penghambat dalam pelaksanaan peran tokoh agama dalam pembinan harmonisasi dan akhlak di lingkungan masyarakat, dan 4) upaya-upaya apa saja yang dilakukan dalam megatasi hambatan pelaksanaan peran tokoh agama dalam pembinan harmonisasi dan akhlak di lingkungan masyarakat.

\section{Metodologi Penelitian}

Penelitian ini merupakan penelitian yang bersifat kualitatif, yaitu suatu pendekatan penelitian yang menghasilkan data deskriptif berupa data-data tertulis/lisan dari orang-orang dan perilaku yang dapat diamati. ${ }^{3}$ Bentuk penelitian ini adalah penelitian kualitatif deskriptif, yaitu penelitian yang menggambarkan objek yang berkenaan peran tokoh Agama dalam pembinaan harmonisasi kehidupan dan akhlak masyarakat di kota Metro Lampung.

Subjek penelitian ini tentang pembinaan harmonisasi kehidupan dan akhlak masyarakat di kota Metro Lampung adalah beberapa tokoh agama dan terutama kiai dan asatidz di kota Metro serta masyarakat. Penelitian ini menggunakan dua data yaitu: 1) Data primer yang langsung dikumpulkan dari sumber pertamanya. Seperti tokoh agama di lingkungan masyarakat khususnya terkait dengan fokuspenelitian. 2) Data sekunder yang dikumpulkan sebagai penunjang dari sumber pertama. ${ }^{4}$ Berupa dokumen-dokumen seperti keadaan geografis lingkungan masyarakat, profile lingkungan

${ }^{3}$ Lekxy J Moleong , Metodologi Peneltian Kualitatif, (Bandung: Remaja Rosdakarya, 2003), h.4.

${ }^{4}$ Sumadi Suryabrata, Metodologi Penelitian, h.85 
masyarakat, program kerja lingkungan masyarakat dan lain sebagainya.

Untuk memperoleh informasi yang jelas, tepat dan lengkap maka penulis menggunakan beberapa metode pengumpulan data yaitu; observasi, wawancara dan dokumentasi. Untuk menjamin keabsahan data digunakan triangula teknikdan triangulasi sumber. Berdasarkan wujud dan sifat data tersebut maka teknik analisa data yang digunakan dalam penelitian ini adalah analisa data kualitatif deskriptif. $^{5}$ menggunakan langkah-langkah Miles dan Huberman

\section{B. Harmonisasi dan Akhlak Masyarakat}

Akhlak adalah keseluruhan pola tingkah laku, sifat-sifat, kebiasaan-kebiasaan, serta unsur-unsur psikofisik lainnya yang selalu menampakan diri dalam kehidupan seseorang. Karakter anak merupakan susunan dinamis psikologis dalam diri anak yang menentukan dirinya dapat atau tidak menyesuaikan diri dengan lingkungan.

Akhlak merupakan kualitas moral dan mental seseorang yang pembentukannya dipengaruhi oleh faktor bawaan (fitrah nature) dan lingkungan (sosialisasi atau pendikan - nurture). Potensi karakter yang baik dimiliki manusia sebelum dilahirkan, tetapi potensi tersebut harus terus-menerus dibina melalui sosialisasi dan pendidikan sejak usia dini.

Akhlak adalah tingkah laku manusia ketika dianalisis dapat digolongkan ke dalam 3 aspek atau fungsi yaitu: a). Aspek kognitif (pengetahuan) yaitu pemikiran, ingatan, hayalan, daya bayang, inisiatif, kreativitas, pengamalan dan penginderaan,

${ }^{5}$ Mathew and Huberman, Analisis Data Kualitatif, (Jakarta : Universitas Indonesia, 1992),h. 15-16. 
fungsi aspek kognitif adalah menunjukkan jalan, mengarahkan dan mengendalikan tingkah laku dan b). Aspek afektif yaitu bagian kejiwaan yang berhubungan dengan kehidupan alam perasaan atau emosi, sedangkan hasrat, kehendak, kemauan, keinginan, kebutuhan, dorongan dan elemen motivasi lainnya di sebut aspek kognitif atau psikomotorik (kecenderungan) yang tidak dapat dipisahkan dengan aspek lain.

Mengacu pada aspek-aspek inilah Para tokoh agama harus tetap berpegang pada pengertian manusia sebagai satu kesatuan yang utuh, yaitu manusia yang berkehendak, berperasaan, berfikir dan berbuat. Demikianlah pula dalam pembahasan tentang karakter, walaupun dianalisis satu persatu tentang aspekaspek kepribadian, kita harus tetap berpegang pada kebutuhan dan keutuhan kepribadian sebagai suatu organisasi jiwa raga yang dinamis, analisis aspek kepribadian hanyalah untuk memperdalam pemabahaman dan pengertian manusia.

Konferensi Internasional Pendidikan Islam ke -1 di Makkah tahun 1977 disebutkan bahwa pendidikan mencakup tiga pengertian sekaligus, yakni ta'lim, ta'dib dan tarbiyah. ${ }^{6}$ Jadi ada tiga istilah yang diartikan dengan pendidikan. Menurut 'Abd al Fatah Jalal, istilah ta'lim lebih tepat untuk menunjuk konsep pendidikan menurut Al Qur'an, karena istilah tersebut mengandung makna lebih luas dari pada tarbiyah. ${ }^{7}$ Sedangkan Syed Muhammad Al Naquid al Attas berpendapat bahwa istilah ta'dib lebih tepat untuk menunjuk pengertian pendidikan. Konsep ta'dib mencakup integrasi antara ilmu dan amal sekaligus. ${ }^{8}$ Adapun istilah tarbiyah berasal dari tiga kata yaitu: pertama kata robba-yarbu yang berarti zada wa nama atau

${ }^{6}$ Chabib Thoha, Kapita Selekta Pendidikan Islam, (Jakarta : Grafindo, 1996) h. 11

${ }^{7}$ Abd al Fatah Jalal, Min al Ushul al tarbiyah fil al Islam, (Mesir : Dar al Fikr, 1997) h. 27

8 Syed Muhammad al Naquid al Attas, Konsep Pendidikan Islam, (Bandung : Mizan, 1990) h.60 
(bertambah dan tumbuh), seperti terdapat dalam Al Qur'an Surat Ar Rum 39. kedua, kata robiya-yarubbu dengan mengikuti wazan mada yamuddu yang berarti memperbaiki, menguasai urusan, menuntun, menjaga dan memelihara. Ketiga, merujuk pada mufrodad al fadz al Quran, ${ }^{9}$ kata tarbiyah merupakan akar kata robb yang berarti mengembangkan sesuatu. ${ }^{10}$

Kata tarbiyah itu sendiri mengandung empat unsur nilai, yaitu: 1)menjaga dan memelihara fitrah manuasia: 2) mengembangkan seluruh potensi; 3) mengarahkan seluruh fitrah dan potensi menuju kesempurnaan ; 4) dilaksanakan secara bertahap. Dari uraian tersebut dapat disimpulkan bahwa tarbiyah (pendidikan) merupakan usaha mengembangkan seluruh potensi anggota masyarakat secara bertahap menuju kesempuraan.

\section{Peran Ulama dalam Pendidikan dan Pembinaan Masyarakat}

Pengertian sistem pendidikan adalah keseluruhan komponen pendidikan yang saling terkait secara terpadu untuk mencapai tujuan pendidikan.Sedangkan Istilah Pondok barangkali berasal dari pengertian asrama-asrama para masyarakat yang disebut pondok atau tempat tinggal yang dibuat dari bambu atau berasal dari kata arabfunduq yang berarti hotel atau asrama. Perkataan lingkungan masyarakat berasal dari kata masyarakat, yang dengan awalan pe di depan dan akhiran an berarti tempat tinggal para masyarakat. ${ }^{11}$ Selain itu, asal kata lingkungan masyarakat terkadang dianggap gabungan dari kata sant (manusia baik) dengan suku kata tra (suka menolong)

\footnotetext{
${ }^{9}$ Al Roghib al Isfahani, Mufrodat alfadz al Qur'an, (Damaskus : Dar al Qalam, 1992) h. 336

10 Abd al Rohman al Nahkawi, Ushul al tarbiyah al Islamiyah wa Asalibuha (Damaskus : Dar al Fikr 1992) h. 32

${ }^{11}$ Zamakhsyari dhofier, tradisi lingkungan masyarakat:studi tentang pandangan hidup Tokoh Agama , (Jakarta:LP3ES, 1985), h.18
} 
sehingga kata lingkungan masyarakat dapat berarti "tempat pendidikan manusia baik" ${ }^{12}$

Pendidikan akhlak menurut T Lickona, E. Schaps, dan Lewis, pendidikan karakter harus didasarkan pada sebelas prinsip berikut: 1) Mempromosikan nilai-nilai dasar etika sebagai basis karakter. 2) Mengidentifikasi karakter secara komprehensif supaya mencakup pemikiran, perasaan, dan perilaku.3)Menggunakan pendekatan yang tajam, proaktif, dan efektif untuk membangun karakter. 4) Menciptakan komunitas sekolah yang memiliki kepedulian. 5) Memberi kesempatan kepada siswa untuk menunjukkan perilaku yang baik. 6) Memiliki cakupan terhadap kurikulum yang bermakna dan menantang yang menghargai semua siswa, membangun karakter mereka dan membantu mereka sukses. 7) Mengusahakan tumbuhnya motivasi diri pada para siswa. 8) Memfungsikan seluruh staf sekolah sebagai komunitas moral yang berbagi tanggung jawab untuk pendidikan karakter dan setia pada nilai dasar yang sama. 9) Adanya pembagian kepemimpinan moral dan dukungan luas dalam membangun inisiatif pendidikan karakter. 10) Memfungsikan keluarga dan anggota masyarakat sebagai mitra dalam usaha membangun karakter. 11) Mengevaluasi karakter sekolah, fungsi staf sekolah sebagai guru-guru karakter, dan manifestasi karakter positif dalam kehidupan siswa. ${ }^{13}$

Sistem pendidikan di lingkungan masyarakat tradisional atau sering disebut lingkungan masyarakat Islam klasik atau lingkungan masyarakat salafi menitik beratkan pada sistem pendidikan dengan mengajarkan kitab-kitab Islam klasik (kitab kuning) sebagai inti pendidikan. Disebut "kitab kuning" karena

${ }^{12}$ Wahjoetomo, perguruan Tinggi Lingkungan masyarakat, (Jakarta: Gema Insani press, 1997), h.5

${ }^{13}$ Zubaedi, Desain Pendidikan Karakter: Konsepsi dan Aplikasinya dalam Lembaga Pendidikan h. 112

Fikri, Vol. 3, No. 1, Juni 2018 
warna kertas edisi-edisi kitab kebanyakan berwarna kuning yang dikarang para ulama terdahulu. Menurut Hasbullah, seiring dengan berkembangnya metode pendidikan Islam, pola interaksi sosial para masyarakat, serta perkembangan budaya ilmu pengetahuan dan teknologi, lambat laun lingkungan masyarakat berubah Dengan mengintegrasikan antara pola pendidikan yang bersifat tradisional dengan sekolah formal. Kebanyakan lingkungan masyarakat telah mengambil pengajaran pengetahuan umum sebagai suatu bagian yang juga penting dalam pendidikan lingkungan masyarakat, namun pengajaran kitab-kitab Islam klasik masih diberi porsi yang penting. Biasanya pelajaran dimulai dengan kitab-kitab yang sederhana, kemudian dilanjutkan dengan kitab-kitab yang lebih mendalam dan tingkatan suatu lingkungan masyarakat bisa diketahui dari jenis kitab-kitab yang diajarkan. ${ }^{14}$

Kondidi di atas juga didukung hasil penelitin Junanah, Widodo Brotowiyono, Asep Supriyadi, Rendi Bayu Aditya, Muhammad Irwan Dan Putrid Fazriyanti yang dilakukan pada tahun 2014 terkait dengan persepsi dan peran tokoh Agama Islam di Kabupaten Sleman dalam upaya Pengelolaan Lingkungan Hidup yang dipublikasikan pada Jurnal Sains dan Teknologi Lingkungan.

Pola hubungan antara Tokoh Agama dengan masyarakat di atas, padagillirannya mendudukan Tokoh Agama pada posisi yang sangat penting di matamasyarakat. Selain sebagai sumber ilmu pengetahuan, Tokoh Agama juga berposisisebagai sumber nilai, sehingga ucapan dan perbuatan Tokoh Agama menjadipanutan para masyarakatnya. Bahkan kebanyakan Tokoh Agama di Jawa beranggapanbahwa suatu lingkungan masyarakat dapat diibaratkan sebagai suatu kerajaan kecildi

${ }^{14}$ Hasbullah, Sejarah Pendidikan Islam di Indonesia:Lintasan Sejarah Pertumbuhan dan Perkembangan, (Jakarta: PT Raja Grafindo Persada,1999) h. 144 
mana Tokoh Agama merupakan sumber mutlak dari kekuasaan dankewenangan dalam kehidupan dan lingkungan pendidikan di lingkungan masyarakat. ${ }^{15}$

Kegiatan pembelajaran di lingkungan masyarakat dilakukan berdasarkansukarela dan mengabdi. Tokoh Agama mengajari masyarakat secara sukarela dan semata-mata mengabdi kepada Alloh SWT. Masyarakat menghormatiTokoh Agama dan teman sebayanya secara sukarela dan juga sematamatamengabdi kepada Alloh. Mereka melakukan hal itu karenakeyakinan bahwa imbalan yang disediakan oleh Alloh lebih banyakdan kekal sifatnya. Seperti firman Alloh sebagai berikut:

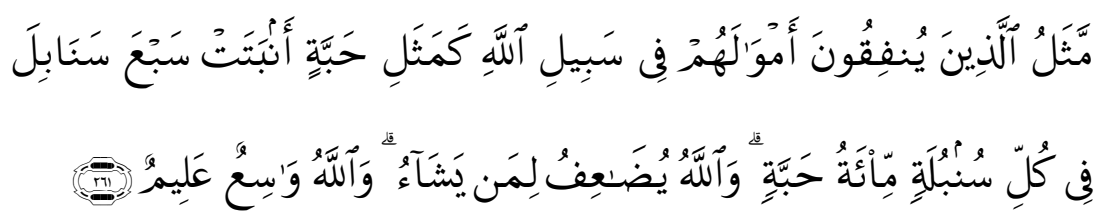

Artinya: perumpamaan (nafkah yang dikeluarkan oleh) orangorang yang menafkahkan hartanya di jalan Allah adalah serupa dengan sebutir benih yang menumbuhkan tujuh bulir, pada tiaptiap bulir seratus biji. Allah melipat gandakan (ganjaran) bagi siapa yang Dia kehendaki. dan Allah Maha Luas (karunia-Nya) lagi Maha mengetahui. (QS. Al-Baqarah: 261) ${ }^{16}$

Pada sebagian masyarakat, kehidupan beragama belum menggambarkan penerapan nilai-nilai ajaran agama yang dianutnya. Keberagaman masyarakat masih pada simbol-simbol keagamaan dan belum pada subtansi nilai-nilai agama. Misalnya, tidak adanya kolerasi antara peningkatan pengetahuan dan praktek keagamaan dengan perbaikan sistem danstuktur sosial. Peningkatan jumlah rumah ibadah tidak

${ }^{15}$ Zamakhsyari Dhofier, Tradisi Lingkungan masyarakat: Studi Tentang Pandangan Hidup Tokoh Agama , h. 56

${ }^{16}$ Al-Qur'an Al-Karim dan Terjemah Bahasa Indonesia , h. 44

Fikri, Vol. 3, No. 1, Juni 2018 
menyebabkan naiknya kesejahteraan masyarakat. Tingginya kuantitas jamaah haji tidak diiringi naiknya tingkat solidaritas sosial. Sebaliknya persoalan-persoalan sosial seperti kemiskinan, keterbelakangan, dan anarkisme tetap marak ditengah naiknya angka kuantitatif keberagamaan masyarakat.

\section{Hasil Penelitian dan Pembahasan}

Temuan penelitianyang berkaitan dengan peran tokoh agama sebagai sebagai figur contohdapat dikemukakan bahwa lingkungan masyarakat sebagai sebuah lembaga pendidikan memilikikekhususan yaitu murid/masyarakat hidup bersama dengan tokoh agama secara membaur. Kondisi ini menyebabkan adanya pola hubungan yang akrab dan erat antara tokoh agama dengan masyarakatnya. Perilaku yang ditampilkan oleh para tokoh agama dalam kehidupan sehari-hari dapat dilihat dan ditiru oleh para masyarakatnya.

Hasil wawancara lain juga mengungkapkan bahwa pelaksanaan pembentukan akhlak masyarakat memerlukan dan waktu yang lama secara terus menerus, karena aspek yang ingin dikembangkan bukanlah hanya kognitif semata-mata melainkan mencakup semua aspek kehidupan termasuk didalamnya nilainilai ketuhanan. Proses internalisasi nilai-nilai akhlak berlangsung secara dialektik dan simultan antara tahap pemahaman, pengendapan, dan pempribadian nilai-nilai akhlak. Oleh karena itu, pengajaran, bimbingan dan latihan dari tokoh agama sangat diperlukan.

Hasil wawancara dengan tokoh agama dalam mendisiplinkan masyarakat juga mengngkapkan bahwa tindakan tegas terhadap pelanggaran atau kesalahan masyarakat dilaksanakan, tidak dalam bentuk hukuman dengan cara apapun juga, melainkan dengan cara-cara pendidikan yang mendorong masyarakat untuk menyadari kesalahannya dan memiliki 
komitmen untuk memperbaiki diri sehingga pelanggaran atau kesalahan tidak terulang.

Kekuatan yang menjadi faktor pendukung peran tokoh agama dalam pembinaan akhlak di lingkungan masyarakat kota Metro terungkap dari hasil wawancara dengan salah satu tokoh agama yang mengemukakan bahwa pembentukan akhlakmasyarakat didukung dengan adanya kekuatan yang ada pada masyarakat khususnya kondisi agamis yang ada dilingkungan masyarakat. Kehidupan lingkungan masyarakat yang agamis di sekitar pondok lingkungan masyarakat dapat dilihat dari kehidupan keluarga sebagai tempat lahir anak dan tempat pertama menerima pendidikan dengan sendirinya dan pembentukan kepribadian dan waktak terlaksana dengan keluarga di sekitar pondok dalam lingkungan masyaraka

Kekuatan yang dimiliki tokoh agama adalah kerjasama yang terjalin baik antara pondok, madrasah, pengurus dan masyarakat setempat. Pondok sebagai lembaga pendidikan di mana masyarakat tinggal dan madrasar sebggai lembaga pendidikan masyarakat serta masyarakat di mana masyarakat berinteraksi setiap hari memiliki keterkaitan erat serta hubungan kerja sama yang saling menguntungkan dalam pembinaan akhlak masyarakat.

Bentuk partisipasi para ulama dan tokoh masyarakat terungkap dalam wawancara dengan salah satu dewan asatidz yang mengemukakan bahwa partisipasi para ulamadan tokoh masyarakat dilakukan baik bersifat langsung maupun tidak langsung. Secara langung para tokoh ulama dan tokoh masyarakat dapat memberikan bantuan baik yang bersifat bantuan dana maupun dukungan kegiatan yang dilaksanakan di lingkungan masyarakat.

Kelemahan yang menjadi faktor penghambat pelaksanaan peran peran Tokoh Agama dalam pembinaan akhlak masyarakat khususnya terkait dengan faktor penghambat berupa sumber 
daya manusia dalam hal ini adalah para asatidz dan pengurus pondok lingkungan masyarakat yang perlu untuk terus meningkatkan profesionalisme dan tingkat pendidikan yang lebih tinggi. Hal ini merupakan tuntutan perkembangan jaman dan tuntutan perkembangan ilmu pengetahuan yang menuntut para asatidz mengembangkan diri dan potensinya agar bisa terus mengembangkan diri dan pondok lingkungan masyarakat. Hal ini sejalan dengan hasil penelitian Novyan Hardar Syaifulloh yang dilaksanakan pada tahun 2013 tentang Peranan tokoh agama dan perilaku santri di pondok pesantren. Dari penelitian tersebut juga disimpilkan bahwa peran tokoh agama dalah hal ini kiai dan dewan asatidz sangatlah menentukan perilaku dan kepribadian para santri dan masyarakat sekitar.

Dana operasional pembinaan akhlak dilingkungan masyarakat untuk kegiatan pendidikan masih sangat perlu untuk ditingkatkan. Memang para masyarakatyang mau memasuki lembaga pendidikan harus mengeluarkan biaya, baik itu biaya langsung maupun tak langsung, namun biaya tersebut belum sepenuhnya mampu membiayai operasional.

Hasil temuan penelitian tentang upaya yang dilakukan dalam mengatasi hambatan pelaksanaan peran Tokoh Agama dalam pembinaan harmonisasi kehidupan akhlak masyarakat dilakukan sesuai dengan kelemahan di lingkungan masyarakat tersebut dilakukan melalui pembinaan akhlak masyarakat dapat dikemukakan bahwa menjaga masyarakatdari efek yang ditimbulkan oleh teknologi informasi sangat sulit untuk dilakukan. Hal ini sebagaimana hasil penelitian Allen Permana. Terkait dengan Peran komunikasi tokoh agama dalam menekan tingkat konsumsi miras di kalangan remaja dalam masyarakat sebagai akibat dari modernisasi dan pla komunikasi juga sangat penting. Namun upaya tersebut harus dilakukan. Sedangkan temuan penelitian juga mengungkapkan bahwa dalam upaya menanggulangi efek teknologi informasi harus terus dilakukan 
pembinaan secara masif kepada masyarakat. Hasil temuan penelitian juga mengungkapkan bahwa serangkaian upaya pengembangan profesionalisme sumber daya manusia yang ada di lingkungan masyarakat telah dilaksanakan melalui berbagai kegiatan.

\section{E. Penutup}

\section{Kesimpulan}

Berdasarkan hasil temuan penelitian dan pembahasan, maka dapat dikemukakan beberapa kesimpulan sebagai berikut:

a. Peran tokoh agama dalam pembinaan harmonisasi kehidupan dan akhlak masyarakat dapat berbentuk sebagai figur contoh. Peran tokoh agama dalam masyarakat juga dilakukan sebagai pengajar, pendidik dan pembimbing serta pelatih dalam berbagai hal yang terkait dengan agama dan pelaksanaannya. Peran tokoh agama juga dilaksanakan dalam bentuk penegak aturan dan kedisiplinan dalam kehidupan bermasyarakat sehingga harmonisasi damsyarakat dalam keberagaman dan kebhenekaan dapat diwujudkan.

b. Kekuatan yang menjadi faktor pendukung peran tokoh agama dalam pembinaan harmonisasi kehidupan dan akhlak masyarakat: a) Lingkungan masyarakat agamis dan banyaknya pondok pesantren di lingkungan masyarakat, b) Kerjasama yang terjalin baik antara pondok, madrasah, pengurus dan masyarakat setempat, serta c) Partisipasi dari para tokoh ulama dan tokoh masyarakat.

c. Kelemahan yang menjadi faktor penghambat pelaksanaan peran peran tokoh agama dalam pembinaan akhlak masyarakat di lingkungan masyarakat: a) Faktor penghambat berupa efek negatif kemajuan teknologi dan 
informasi, b) Faktor penghambat berupa sumber daya mausia (SDM), c) Faktor penghambat berupa kurang memadai sarana dan prasarana keagamaan di masyarakat, d) Faktor penghambat berupa minimnya biaya atau pendanaan sebagai bentuk dukungan pemerintah dan masyarakat

d. Upaya yang dilakukan dalam mengatasi hambatan pelaksanaan peran tokoh agama dalam pembinaan harmonisasi kehidupan danakhlak masyarakat dilakukan melalui himbauan secara massif kepda para masyarakat terutama dalam penggunaan alat komunikasi seperti Handphone melalui program - program tertentu untuk menjaga keseimbangan mental dan akhlak masyarakat. Sosialisasi dan konsolidasi pengurus organisasi keagamaan serta partisipasi masyarakat

\section{Saran}

Berdasarkan kesmpulan di atas dapat dikemukakan beberapa saran yaitu: 1) untuk peningkatan peran tokoh agama dalam dalam pembinaan harmonisasi kehidupan dan akhlak masyarakat perlu dilakukan melalui berbagaibentuk kegiatan terutama kegiatan social keagamaan. Hal ini penting untuk menjaga harmonisasi kehidupan terutama kebersamaan dalam bingkai kebhenekaan. 2) Perlu penguatan dari para tokoh agama dan instransi terkait dalam penguatan terhadap factor-faktor yang mendukung peran tokoh agama dalam dalam pembinaan harmonisasi kehidupan dan akhlak masyarakat sertaupaya mengatasi kelemahan yang menjadi penghambt pelaksanaan peran tersebut 


\section{Daftar Pustaka}

Allen Permana. 2015. Peran Komunikasi Tokoh Agama dalam Menekan Tingkat Konsumsi Miras di Kalangan Remaja Kelurahan Malendeng. 2015. Jurnal Acta Diurnal. Vol. 4, No. 5. 1-10

Abd al Fatah Jalal. 1997. Min al Ushul al Tarbiyah fil al Islam, Mesir: Dar al Fikr

Abd al Rohman al Nahkawi. 1992. Ushul al Tarbiyah al Islamiyah wa Asalibuha, Damaskus: Dar al Fikr

Al Roghib al Isfahani, 1992. Mufrodat alfadz al Qur'an, Damaskus: Dar al Qalam

Al-Zarnuji. 2010. Ta'lim Muta'allim, Surabaya: Maktabah Syekh Muhammad bin Ahmad Nabhan, tt

Al-Qur'an dan Terjemahnya. 2006. Jakarta: Syaamil Cipta Media

Chabib Thoha. 1996. Kapita Selekta Pendidikan Islam, Jakarta: Grafindo.

Hasbullah. 1999. Sejarah Pendidikan Islam di Indonesia: Lintasan Sejarah Pertumbuhan dan Perkembangan, Jakarta: PT Raja Grafindo Persada

Junanah, Widodo Brotowiyono, Asep Supriyadi, Rendi Bayu Aditya, Muhammad Irwan Dan Putrid Fazriyanti. 2014. Persepsi dan Peran Tokoh Agama Islam di Kabupaten Sleman dalam Upaya Pengelolaan Lingkungan Hidup. Jurnal Sains dan Teknologi Lingkungan. Vol. 6 No.1 6370

Laurentius Yananto Andi Prasetyo. 2013. Peran Tokoh Lintas Agama dalam Menangkal Gerakan Radikalisme Agama dan Implikasinya terhadap Ketahanan Wilayah (Studi Pada Komunitas Tokoh Lintas Agama di Kota Surakarta, Jawa Tengah). Jurnal Ketahanan Nasional, Vol 14, No.3, 135-145

Lekxy J Moleong. 2003. Metodologi Peneltian Kualitatif, Bandung: Remaja Rosdakarya.

Mathew and Huberman. 1992. Analisis Data Kualitatif, Jakarta:

Universitas Indonesia 
M.Dawam Raharjo. 1985. "Perkembangan Masyarakat dalam Perspektif Lingkungan masyarakat”, Pengantar dalam M. Dawam Raharjo (ed), Pergulatan Dunia Lingkungan masyarakat: Membangun dari Bawah, Jakarta: P3M

Novyan Hardar Syaifulloh. 2013. Studi Peranan Tokoh Agama dan Perilaku Merokok Santri di Pondok Pesantren AlIslah Desa Bandar Kidul Kecamatan Mojoroto Kota Kediri. Jurnal Promkes, Vol. 1. No. 2. 124-131

Suharsini Arikunto. 1991. Prosedur Peneltian Suatu Pendekatan Praktek, Yogyakarta: PT. Rineka Cipta.

Sulthon masyhud et.al. 2003. Manajemen Pondok Lingkungan masyarakat, Jakarta: Diva Pusaka

Sumadi Suryabrata. 1998. Metodologi Penelitian, Jakarta : Raja Grafindo Persada

Syed Muhammad al Naquid al Attas. 1990. Konsep Pendidikan Islam, Bandung: Mizan, 1990

Zainal Abidin Bagir, et.c, 2005. Intergrasi Ilmu dan Agama Interpretasi danAksi, Bandung:Mizan Pustaka

Zamakhsyari dhofier. 1985. Tradisi Lingkungan masyarakat: Studi tentang Pandangan Hidup Tokoh Agama, Jakarta: LP3ES

Zubaedi. 2011. Desain Pendidikan Karakter: Konsepsi dan Aplikasinya dalam Lembaga Pendidikan, Jakarta: Kencana 